\title{
К БИОЛОГИИ ГЛАДКОЙ БРОНЗОВКИ PROTAETIA SPECIOSISSIMA (SCOPOLI, 1786)
}

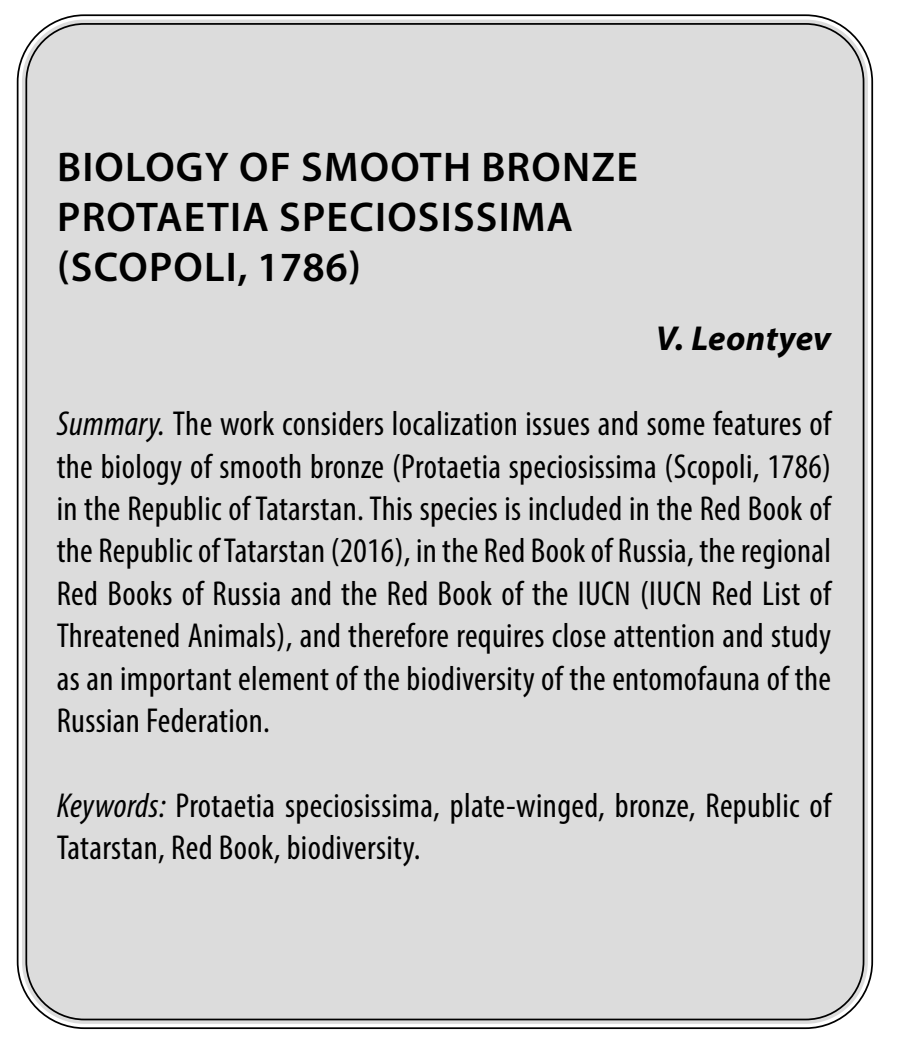

\section{Введение}

ц елью исследования были поиски локализации, изучение биологии редкого вида пластинчатоусых жесткокрылых (Scarabeidae) насекомых, включенного в Красную книгу Республики Татарстан (2016), в Красную книгу России и Красную книгу МСОП (IUCN Red List of Threatened Animals) - бронзовки гладкой (Protaetia speciosissima (Scopoli, 1786)) на территории Республики Татарстан. Данный вид охраняется в Российской Федерации и включен в региональные Красные книги, где встречается данный вид.

\section{ПрироАно-климатическая}

характеристика региона исслеАования

Республика Татарстан расположена в восточной части восточно-европейской, или Русской, равнины, у слияния рек Волги и Камы. Её территория включает северную часть Поволжья и соседствует с Предуральем. Территория республики протянулась с запада на восток на 400 км, с севера на юг на 250 км. Площадь республики 68 тыс. км². Территория представляет со-
Леонтьев Вячеслав Витальевич

К.б.н., доцент, Елабужский институт Казанского федерального университета vleontev@yandex.ru

Аннотация. В работе рассмотрены вопросы локализации и некоторые особенности биологии гладкой бронзовки Protaetia speciosissima (Scopoli, 1786) на территории Республики Татарстан. Данный вид включен в Красную книгу Республики Татарстан (2016), в Красную книгу России, региональные Красные книги России и Красную книгу МСОП (IUCN Red List of Threatened Animals), и, поэтому требует пристального внимания и изучения, как важный элемент биоразнообразия энтомофауны Российской Федерации.

Ключевые слова: Protaetia speciosissima, пластинчатоусые жесткокрылые, бронзовки, Республика Татарстан, Красная книга, биоразнообразие.

бой возвышенную ступенчатую равнину, расчлененную густой сетью речных долин. Широкими долинами Волги и Камы равнина разделена на три части: Предволжье, Предкамье и Закамье. Предволжье с максимальными высотами (276 м) занимает северо-восточную часть Приволжской возвышенности. В Восточное Предкамье с севера заходят южные окончания Можгинской и Сарапульской возвышенностей, разделенные долиной р. Иж. Наибольшие высоты достигают здесь 243 м. Самой высокой в Татарстане (до 381 м) является Бугульминская возвышенность в Восточном Закамье. Самый низкий рельеф (до 200 м) характерен для Западного Закамья. Долины самых крупных рек (Волги, Камы, Вятки) и многих средних (Свияги, Казанки, Шешмы, Зая, Ика, Большого Черемшана) имеют резко выраженную асимметрию склонов, обусловленную смещением русел этих рек вправо под действием силы Кориолиса. Более крутыми являются склоны, обращенные на юг и запад. Преобладание безлесных, открытых пространств, отсутствие крупных массивов болот и крупных водоемов, за исключением Куйбышевского и Нижнекамского водохранилищ, а также расчлененный рельеф способствуют лучшему нагреванию земной поверхно- 


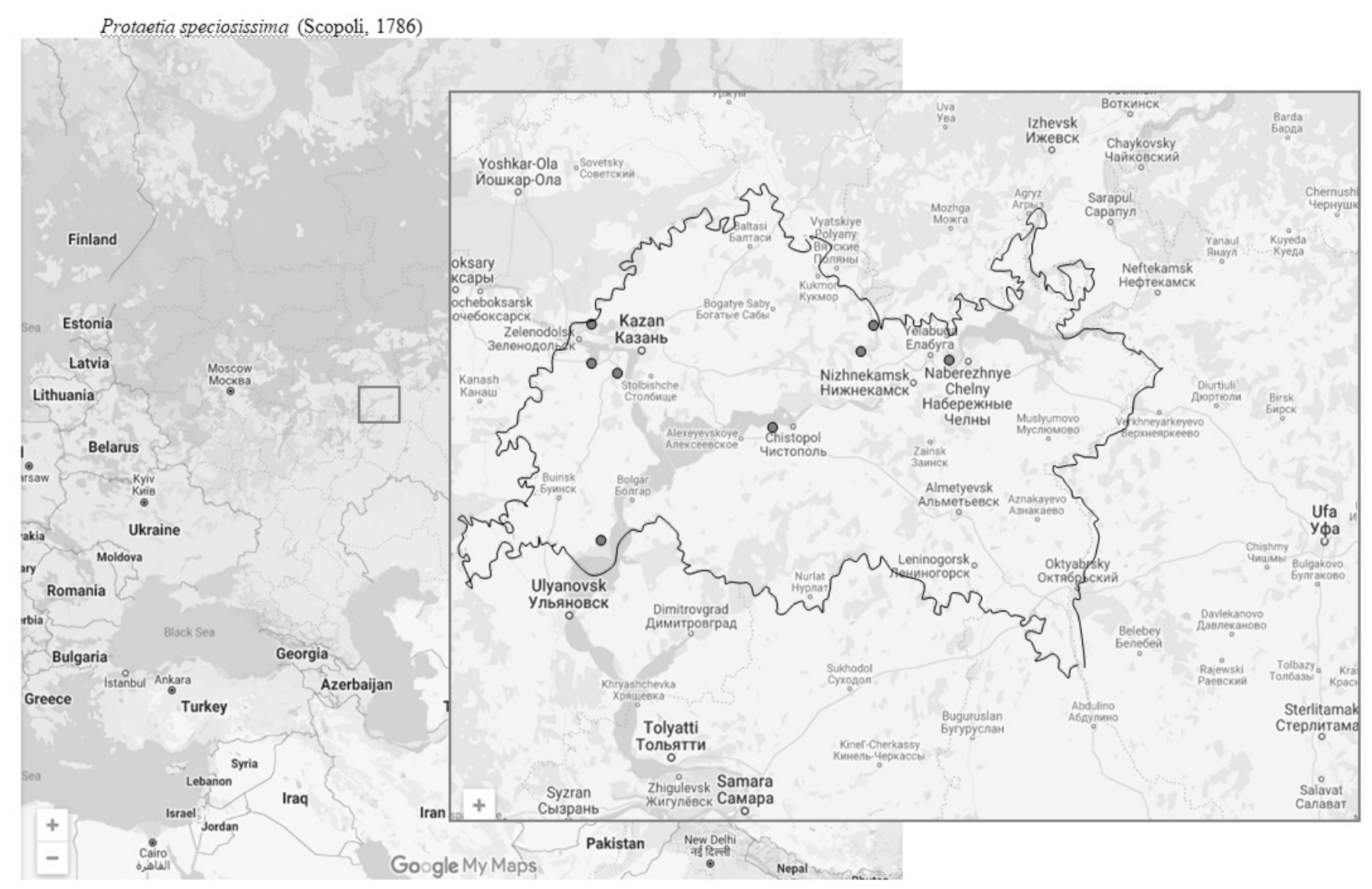

Рис. 1. Локализация Protaetia speciosissima (Scopoli, 1786) на территории Республики Татарстан

сти и воздуха летом, отчего климат становится более резким, континентальным Республика Татарстан расположена на территории двух природных зон - лесной и лесостепной, в переходной полосе от зоны подзолистых почв к зоне черноземов. Здесь широко распространены дерново-подзолистые, серые лесостепные почвы и черноземы (Ермолаев и др., 2007).

\section{Распространение}

Вид широко распространен в Средней и Южной Европе и европейской части Турции: Албания, Австрия, Босния и Герцеговина, Болгария, Беларусь, Хорватия, Европейская часть России, Чехия, Франция, Германия, Греция, Венгрия, Италия, Македония, Молдова, Польша, Румыния, Словакия, Словения, Испания, Швейцария, европейская часть Турции, Украина, Сербия и Черногория (Smetana, 2006).

В России северная граница проходит от Калининградской области на Брянск, Тулу, Елец, Воронеж, Йошкар-Олу, Малмыж, Киров, Оренбург; южная граница проходит по рубежу с Украиной, к Волгограду, по узкой полоске поймы Волги - до ее дельты, Уральск, Орен- бург; на Кавказе и в Крыму отсутствует (Медведев, 1964).

В Среднем Поволжье России вид отмечен в 60-х годах прошлого века (Утробина, 1964). Указан для лесостепи Чувашской Республики, Республики Татарстан, Ульяновской и Самарской областей (Исаев и др. 2004).

\section{Материа^ и методы}

Основными методами регистрации вида являлись использование пахучих ловушек для имаго, ручной сбор и раскопки местообитаний ювенильной фазы. Идентификация видовой принадлежности проводилась по описанию С.И. Медведева (1964).

Нами вид был отмечен в 6 районах Республики Татарстан, на припойменных территориях рр. Волга, Кама, Вятка (рис. 1). В отдельные годы вид отмечался в Зеленодольском районе, окрестностях и черте городов Казань и Елабуга. На территории Раифского участка Волжско-Камского государственного природного заповедника встречается практически ежегодно с 2004 года. Регулярно встречается в Тукаевском райо- 
не (Большой Бор, Национальный парк «Нижняя Кама»). Эти территории являются достоверно известными резерватами сохранения и охраны вида на территории Республики Татарстан.

\section{материал}

Тукаевский р-н: «Большой Бор» («Национальный парк «Нижняя Кама»), окрестности оз. Отарка, 18.VI.2013, на большой вырубке соснового бора, недалеко от дубравы, 1 экз.; 16-17.VI. 2019, вблизи поймы оз. Отарка, на дубе, 2 экз.; 5.VII. 2020, 1 экз.; 22.08.2021, в распиленном дуплистом дубе (после извлечения пчелиных сот местным жителем) - 3 мертвых имаго, 1 мертвый имаго в коконе, 73 кокона, 1 ювенильная фаза; Мамадышский р-н: 21.VII.2017, в широколиственном лесу у д. Старый Черкас, 1 экз. (все - В.В. Леонтьев).

\section{Биология}

Вид с евро-переднеазиатским типом ареала. Имаго - лимфофлоссофаг, ювенильная фаза - мицетоксилофаг. Стенотопный вид. Преимущественно держится в больших старых широколиственных лесах (клен, береза, дуб) и садах, среди древесных крон и на стволах с вытекающим соком. Лет с конца мая до третьей декады сентября, преимущественно со второй половины июня до середины августа. В период размножения (июнь-июль) встречается на опушках, полянах, или под пологом леса. Обычно летает днем. Иногда встречается в смешанных лесах. Жуки больших скоплений не образуют, встречаются чаще одиночно.

По данным E. Rössner (Rössner, 2012) развитие генерации длится пять лет. Личинки развиваются в верхней части ствола, и в области верхушки различных лиственных деревьев - дуб черешчатый (Quercus robur L., 1753, бук европейский (Fagus sylvatica L., 1753), липа сердцевидная (Tilia cordata Mill., 1768), яблоня (Malus sylvestris (L.) Mill.), береза повислая (Betula pendula Roth.), а также хвойных пород - сосна обыкновенная (Pinus sylvestris L., 1753), при условии, что ствол имеет достаточный объем и поражен грибком, который размягчает древесину (Möller, 2009). Личинки развиваются в дуплах старых деревьев и нередко под валежинами, в увлажненной трухлявой древесине и пнях лиственных деревьев (дуб черешчатый (Quercus robur L., 1753), клен остролистный (Acer platanoides L., 1753), фруктовые деревья) (Медведев, 1964). Вероятно, одним из основных объектов питания личинок является мицелий дереворазрушающих грибов, развитие которых зависит от условий увлажнения. Цикл развития, вероятно, двухлетний. Нами были обнаружены личинки и пустые коконы (73 шт. в одном дереве) в нижней части ствола дуплистого дуба, о чем будет описано далее.

\section{Категория угрозы \\ исчезновения таксона в России \\ по критериям МСОП: ЕN}

Не смотря на малочисленность вида, на территории Республики Татарстан сохраняются устойчивые популяции, благодаря их расположению на особо охраняемых природных территориях: Волжско-Камский государственный природный заповедник и Национальный парк «Нижняя Кама».

\section{Результаты исслеАования и их обсужАение}

Летний сезон 2021 года выдался не удачным для развития многих видов бронзовок: жаркие июнь и июль температура воздуха достигала $37-39{ }^{\circ} \mathrm{C}$, осадки отсутствовали. За весь летний период встречалось лишь несколько особей золотистой, металлической, мраморной и вонючей бронзовок. Хотя в предыдущие годы эти виды были обычными и массовыми. Живые особи гладкой бронзовки не встречались вообще. Пахучие ловушки, установленные в дубравах, также не давали результатов.Особый интерес в рамках данного исследования представляла небольшая дубрава, расположенная узкой полосой в «Большом Бору», на территории ФГБУ «Национальный парк «Нижняя Кама», на побережье озер Отарка и Брод, протяженность которой составляет 1380 метров, а в поперечнике - всего 40-50 метров. С севера от дубравы расположены сосновые и смешанные лесные массивы. Раскопки трухлявых пней и дуплистых деревьев позволили выявить постоянное присутствие гладкой бронзовки в районе исследования, помимо единичных ранних встреч. Волей случая здесь, 22.08.2021 г., было обнаружено гнездовье личинок гладкой бронзовки. Оно было обнаружено в распиленном местным жителем дуплистом дубе, где обитала пчелиная семья (рис. 2).

Здесь сохранились фрагменты пчелиных сот. Там же были обнаружены останки и перья галки (Coloeus monedula (Linnaeus, 1758)), которые предпочитают гнездиться в дуплистых деревьях. Свидетельств гнездостроительства галкой не обнаружено. Видимо, в начале гнездового периода птица была убита пчелами при попытке пролезть в дупло.

На дне дупла располагался толстый слой (35-40 см) переработанной личинками бронзовок древесной трухи, имеющую характерную гранулированную структуру. Очевидно, что данное дуплистое дерево использовалось ими много лет. Раскопки позволили выявить достоверное присутствие здесь именно гладкой бронзовки. В итоге в дупле одного дерева было обнаружено: 3 мертвых имаго, 1 мертвое имаго в коконе, 5 надкры- 

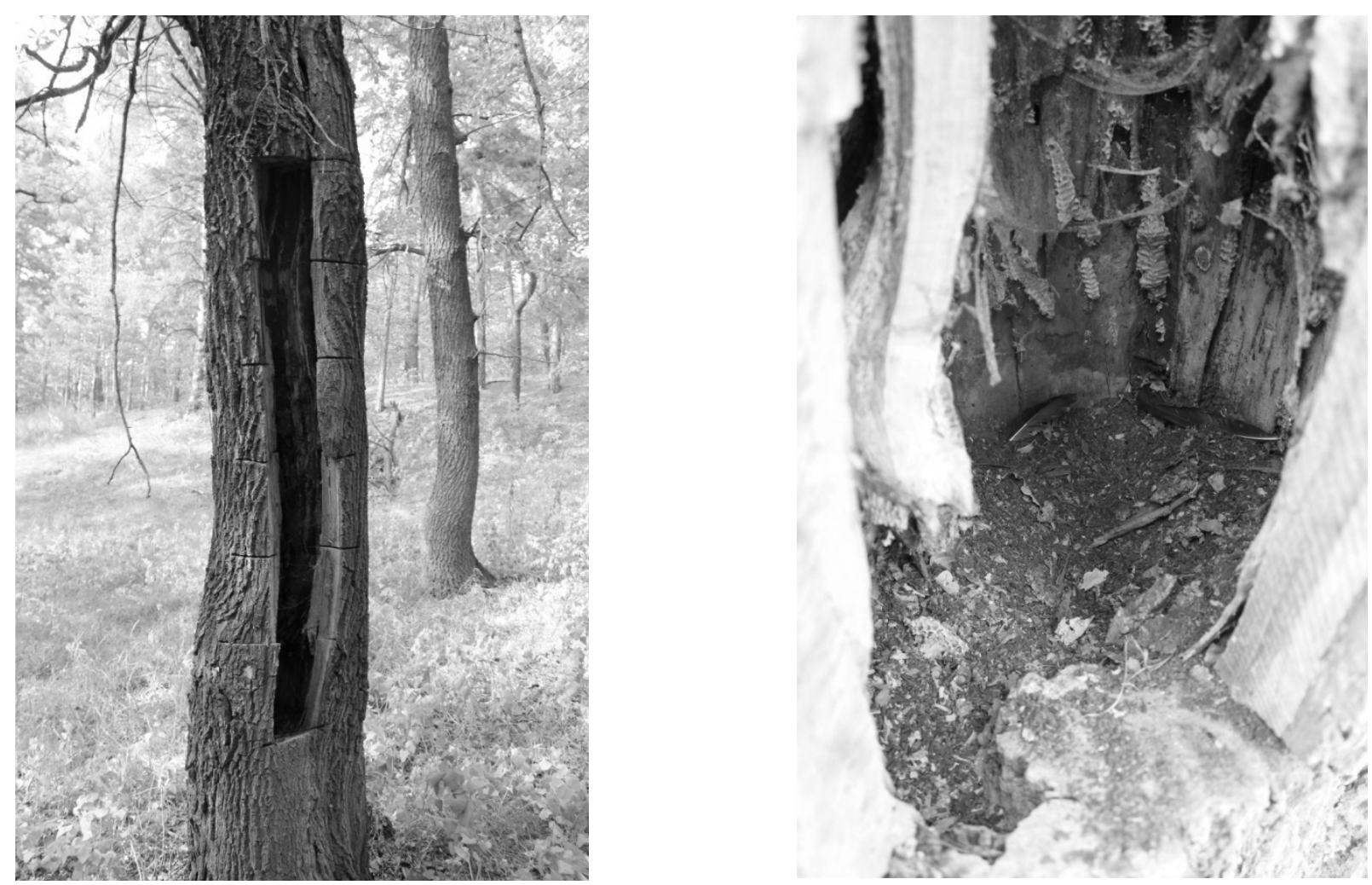

Рис. 2. Гнездовье Protaetia speciosissima в распиленном дубе

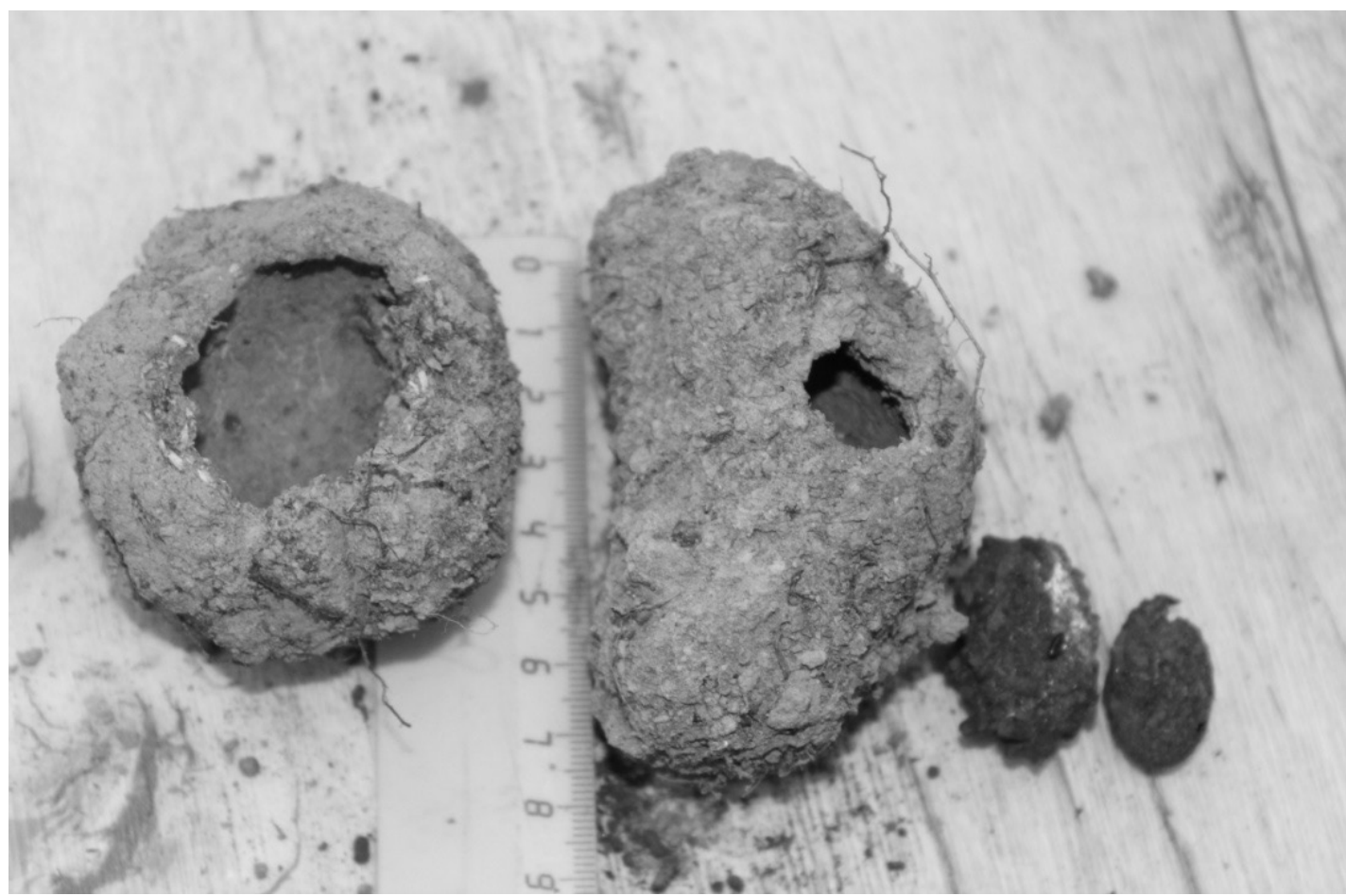

Рис. 3. Коконы скарабеоидных жуков (слева направо): 9 Lucanus cervus Linnaeus, 1758; $\widehat{\partial}$ Lucanus cervus Linnaeus, 1758; Protaetia speciosissima (Scopoli, 1786);

Cetonia aurata Linnaeus, 1758 

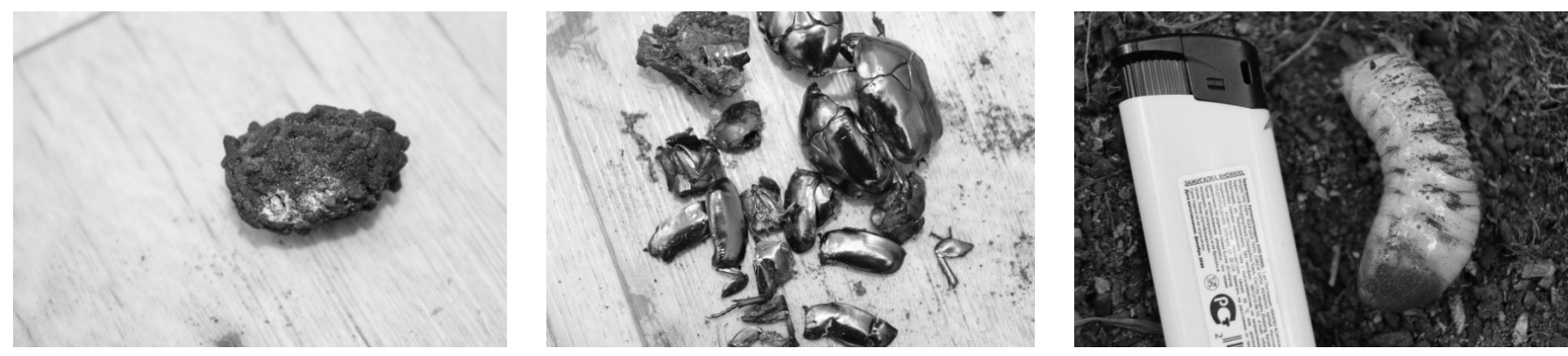

Рис. 4. Слева направо: кокон Protaetia speciosissima (Scopoli, 1786), пораженный «белой» гнилью; останки имаго; личинка

лий и другие фрагменты, 73 пустых кокона, 1 ювенильная фаза.

Средний размер кокона гладкой бронзовки составлял 30×23 мм. Для сравнения - размер кокона мраморной бронзовки составлял $27 \times 18$ мм, золотистой бронзовки - 25×15 мм. Коконы жука-оленя имели размеры: самца - 85×50 мм, самки - 65×55 мм (рис. 3). Коконы бронзовок склеены экскрементами личинки из древесной гранулированной трухи, переработанной самими личинками. Коконы жука-оленя склеены экскрементами личинками из земли. Коконы мраморных бронзовок были обнаружены в трухлявом пне в этом же лесу. Жуки-олени и бронзовка золотистая также обитают в этом лесу, но были обнаружены в другой дубраве, удаленной на несколько десятков километров.

Длина личинки составляла 62 мм - это личинка старшего возраста (рис. 4). После изучения место раскопки было восстановлено, личинка возращена в гнездовье, были изъяты несколько пустых коконов и мертвые имаго.

Обнаружение в дупле мертвых имаго вызывает вопросы. Нередко, личинки, куколки и имаго бронзовок погибают от поражения грибками «белой гнилью» (рис. 4). Этим можно объяснить нахождение мертвого имаго в коконе. Так называемая «бурая гниль» размягчает древесину, что делает ее удобоваримой для личинок, которые также могут использовать в пищу этот грибок. Обнаружение в дупле останков сформированных имаго (рис. 4) можно объяснить другой причиной. Вероятно, останки имаго принадлежат самкам (внешний половой диморфизм не выражен, изучение полового аппарата не проводилось), которые после откладки яиц в дупле завершили свой жизненный цикл.

Здесь возникает еще один вопрос - не характерно ли данному виду явление, называемое «homing», свойственное многим позвоночным и некоторым беспозвоночным (моллюскам, ракообразным и неко- торым перепончатокрылым насекомым). В лесу подобных дуплистых деревьев достаточно, тогда получается, что каждое из них может представлять «родовое имение», а особи, развивающиеся в них, представляют относительно обособленные генетические линии. Данная проблема требует специальных генетических исследований особей данного вида, начиная с личинок, и заканчивая имаго, с маркировкой локальных мест их обитания.

Гладкая бронзовка предпочитает для своего развития дуплистые дубовые деревья, и может сожительствовать с нередко поселяющимися здесь пчелой медоносной, шершнем, летучими мышами, птицами-дуплогнездниками. Очевидно, развиваясь два года на дне дупла, в древесной трухе, личинки бронзовки не вызывают особого беспокойства для сезонно обитающих здесь дуплогнездников.

\section{Зак^ючение}

Так или иначе, можно утверждать, что на данном небольшом дубравном участке обитают стабильные популяции редких значимых видов, обнаруженные попутно в ходе исследования: Protaetia speciosissima (Scopoli, 1786) - Бронзовка гладкая, Lucanus cervus Linnaeus, 1758 - европейский Жук-олень, Zerynthya polyxena Denis \& Schiffermüller, 1775 - Поликсена, Astiodes sponsa Linnaeus, 1767 - Ленточница пурпуровая, или малиновая, Catocala fraxini (Linnaeus, 1758) - Ленточница голубая. В дубраве произрастает кирказон - кормовое растение поликсены. Гусеницы ленточниц питаются листьями дуба. Данные виды занесены в Красную книгу Республики Татарстан (2016), первые два из нихв Красную книгу России (Приказ ..., 2020) и Красную книгу МСОП (IUCN Red List of Threatened Animals). Данные виды ассоциированы с дубом черешчатым (Quercus robur Linnaeus, 1753) как и некоторые виды позвоночных животных (сойка, кабан, лось), поэтому сохранение дубрав имеет важное значение в качестве резерватов биоразнообразия животных. Отрадно, что 
данный небольшой дубравный участок расположен на территории национального парка, что сохраняет его от окончательной вырубки, хотя нередко несанкционированная вырубка высохших обезлиственных дубов местными жителями производится (на окраине дубравы расположен населенный пункт Луговой). Такие деревья являются местом питания и размножения для многих видов беспозвоночных животных. Кроме того, эта дубрава находится в зоне рекреации, располагаясь на побережье озер, и по ее окраине и вдоль, проходит грунтовая дорога. Очевидно, что данному дубравному участку необходимо изменить статус рекреационного использования. Необходимы ограничение вырубки и сохранение старовозрастных деревьев, особенно дуба, липы в широколиственных лесах. Запрет отвода земель под садоводческие общества в приопушечной части леса. Данные мероприятия будут способствовать сохранению биоразнообразия животного и растительного мира на локальных территориях, которые являются резерватами редких и сокращающихся видов.

\section{ЛИТЕРАТУРА}

1. Ермолаев 0.П. и др. Ландшафты Республики Татарстан: региональный ландшафтно-экологический анализ / 0.П. Ермолаев и др.; под ред. проф. 0.П. Ермолаева. Казань: Слово, 2007. 410 c.

2. Исаев А.Ю., Егоров Л.В., Егоров К.А. Жесткокрылые (Insecta, Coleoptera) лесостепи Среднего Поволжья: Каталог. Ульяновск, 2004. 72 с.

3. Красная книга Республики Татарстан: животные, растения, грибы / под гл. ред. А.А. Назиров, зам. гл. ред. Ю.А. Горшков, Д.В. Иванов, Т.В. Рогова. 3-е изд. Казань: Изд-во «Идел-Пресс», 2016.760 с.

4. Медведев С.И. Пластинчатоусые (Scarabaeidae): подсемейства Cetoniinae, Valginae // Фауна СССР: Н.С. № 90. Жесткокрылые; Т. 10. Вып. 5. М.-Л.: Наука, 1964. 375 c.

5. Приказ об утверждении перечня объектов животного мира, занесенных в Красную книгу Российской Федерации № 162 от 24.03 .2020 г.

6. Утробина Н.М. Фауна и распространение пластинчатоусых жуков (Coleoptera, Scarabaeidae) в Среднем Поволжье // Почвенная фауна Среднего Поволжья. М., 1964. С. 67-92.

7. Möller G. 2009. Struktur und Substratbindung holzbewohnender Insekten, Schwerpunkt Coleoptera. Käfer. Dissertation, Freie Universitgt Berlin, 284 pp.

8. Rössner E. 2012. Die Hirschkдfer und Blatthornkäfer Ostdeutschlands (Coleoptera: Scarabaeoidea). Verein der Freunde \& Furderer des Naturkundemuseums Erfurt e.V., Erfurt, $508 \mathrm{pp}$.

9. Smetana A. 2006. Cetoniinae Leach, 1815. In: Löbl I. \& Smetana A.: Catalogue of Palaearctic Coleoptera. Volume 3: 690 pp. Apollo, Stenstrup.

10. IUCN Red List of Threatened Animals. https://www.iucnredlist.org/ 